\title{
SPATIAL ANALYSIS OF INFILTRATION IN AN OXISOL OF THE EASTERN PLAINS OF COLOMBIA
}

\author{
Helber Milton Orjuela-Matta ${ }^{1}$, Yolanda Rubiano Sanabria ${ }^{2}$, and Jesús H. Camacho-Tamayo ${ }^{3 *}$
}

\begin{abstract}
Studies that involve soil attributes variability help the analysis of the behavior of hydrophysical attributes in space, to support the decision-making process within the conception of precision agriculture. The aim of the present paper was to characterize the spatial variability of the surface infiltration and its relation to some soil physical attributes. The sampling was done with a rectangular mesh of 64 points with perpendicular distances of $52 \mathrm{~m} \times 45 \mathrm{~m}$ between sampling points. The attributes studied were bulk density, contents of sand, silt and clay, soil moisture, cumulative infiltration, basic infiltration, sorptivity, and saturated hydraulic conductivity (Ks). Data were analyzed using descriptive statistics and geostatistics, identifying the relationship between attributes, using the Pearson correlation and cluster analysis. Results suggest a behavior of parameters close to normal, attributes related to soil water movement had greater variability, with low basic infiltration $\left(1.46 \mathrm{~cm} \mathrm{~h}^{-1}\right)$ and $\mathrm{Ks}\left(0.80 \mathrm{~cm} \mathrm{~h}^{-1}\right)$, which together with high values of bulk density $\left(1.87 \mathrm{~g} \mathrm{~cm}^{-3}\right)$ show limitations by compaction. Cumulative infiltration and Ks attributes did not fit to models of spatial distribution, finding ranges of $150 \mathrm{~m}$ for the other attributes, distance to optimize future sampling for the study of spatial variability. Pearson correlation and cluster analysis allowed establishing relationships between soil attributes; spatial relationships were corroborated in contour maps, where we observed the influence of clay and sand content in the behavior of bulk density, and the influence of these attributes in processes of water infiltration into the soil.
\end{abstract}

Key words: Geostatistics, hydraulic conductivity, infiltration, sorptivity.

$\mathrm{T}$ he need to satisfy the present and growing demand for food stimulates the development of research related to the management and use of water, an essential factor for increasing agricultural production, since an efficient application of water fundamentally depends on the infiltration capacity of the soil (Machiwal et al.,2006). At the same time, characterizing the infiltration process constitutes one of the basic parameters of the adequate design and management of the risk systems in agricultural production.

Water infiltration in the soil occurs through a combination of flow directions, vertically as well as horizontally. Frequently, determination of the infiltration rate is carried out in the field through the use of ring, individual or double. The use of an individual ring is inadequate, especially when the ring diameter is less than $15 \mathrm{~cm}$, due to the border effect (Tricker, 1978) where the lateral flow raises the infiltration rate, which leads to basic

${ }^{1}$ Universidad de Cundinamarca, Facultad de Ciencias Agropecuarias, Sede Fusagasugá, Colombia.

${ }^{2}$ Universidad Nacional de Colombia, Facultad de Agronomía, Sede Bogotá, Colombia.

${ }^{3}$ Universidad Nacional de Colombia, Facultad de Ingeniería, Sede Bogotá. Ciudad Universitaria, Ed. 214, Of. 304, Bogotá, Colombia. "Corresponding author (jhcamachot@unal.edu.co).

Received: 30 August 2011.

Accepted: 22 June 2012. infiltration values above the real capacity of the soil and whose result is an inappropriate design of risk systems (Reynolds and Elrick, 1990).

According to Wu et al. (1997), the infiltration rate is similar for double and for individual cylinders at the first moment of the infiltration process, especially in soils of a clay texture (which show low infiltration rates). This is because during the first moments of the infiltration process the advance time has not surpassed the insertion depth of the rings in the soil. Once it reaches this depth, there is a marked difference in the infiltration behavior, since in the infiltration determined with double rings the lateral flow of the internal ring is limited (Youngs, 1987).

Infiltration is a complex physical process in time and space (Rodríguez-Vásquez et al., 2008), which is difficult to characterize with precision under the intrinsic heterogeneous and dynamic soil conditions, which affect the texture, compaction, humidity regime, slope, thickness of the horizons, root development and soil aggregation. On the other hand, attributes hydrophysical influence many hydrological processes including infiltration, runoff erosion process, percolation and redistribution of pesticides leaching and migration of contaminants through the soil profile (Bagarello et al., 2010). The precise determination of the water infiltration rate in the soil helps to minimize the risks of degradation, especially with the process of surface runoff. 
There are techniques for studying the spatial behavior of the infiltration, such as descriptive statistics and geostatistics, which permit the elaboration of linear and spatial models of infiltration, its relation to the soil physical attributes (texture, bulk density, porosity and water content), which also varies in space and directly influences the flow and water storage in the soil (RodríguezVásquez et al., 2008). For the use of descriptive statistics in the study of the soil attributes, samples are analyzed to characterize a region, where the number of these is generally low and is conditional upon prior knowledge of the study area or looking for recommendations tolerance given by a confidence limit that is accurate (Mallants et al., 1996). According to Reynolds et al. (2002), there is no way to predetermining the number of samples required, as this depends on the variability of the attributes, generally unknown. In the absence of use of other tools for a better estimate, the characterization of soil attributes is done using measures of location (mean, median, minimum and maximum), dispersion (coefficient of variation - CV) and shape (skewness and kurtosis).

The use of these techniques has limitations, since soil attributes are analyzed individually and does not identify the different interactions between them (Borůvka et al., 2002). Furthermore, the $C V$ is sensitive to sample distance and the number of samples: the greater the distance of the sampling the greater the values of CV shown (Garten et al., 2007) and with an increasing number of samples, the CV tends to diminish (Dong-Sheng et al., 2011), which can lead to erroneously declaring that the variability is low. Furthermore, it does not permit defining the spatial variability, since this technique does not give information about the pattern of spatial distribution of a particular attribute, which makes it impossible to establish management units.

Knowing the spatial variability of the soil permits a better understanding of the complex relationships between its characteristics and environmental factors (Goovaerts, 1999), and helps in determining specific management practices for its adequate use (Plant, 2001). Recognition of the variability leads to reevaluating the conventional soil management in agricultural production, which assumes a homogeneous behavior of the soil attributes, and general recommendations are used. In the case of infiltration and hydrophysical attributes, the construction of spatial models permits the planning and localized management of the water in the irrigation processes, according to soil characteristics and crop supplies (Martins et al., 2010).

The objective of the present study was to characterize the spatial variability of the surface infiltration and its relation to some soil physical attributes (Typic Haplustox) in the Eastern Plains (Llanos Orientales) of Colombia, using statistical methods, which support the localized management of soil and water in agricultural systems that are within the framework of the precision agriculture.

\section{MATERIALS AND METHODS}

The research was carried out at the Taluma Experimental Station of the Colombian Corporation for Agricultural Research (CORPOICA), located in the municipality of Puerto López $\left(4^{\circ} 22^{\prime}\right.$ N, $72^{\circ} 13^{\prime} \mathrm{W}$; $156 \mathrm{~m}$ a.s.1.), Meta, Colombia. The zone has a humid tropical forest climate, with an average temperature of $27{ }^{\circ} \mathrm{C}$, relative humidity of $75 \%$, and a unimodal rain distribution concentrated between April and November, with an average of $2375 \mathrm{~mm}$ (Jaimes et al., 2003). The predominant soil is a Typic Hapolustox, with a coarse loam phase over a fine loam, slope slightly inclined $(<5 \%)$, susceptible to physical degradation, under extensive cattle raising with native grasslands (Trachypogon vestitus Andersson).

For the soils sampling a rectangular mesh of 64 points was used, maintaining perpendicular distances of $52 \mathrm{~m} \times$ $45 \mathrm{~m}$, where samples were taken between 0 and $0.1 \mathrm{~m}$ of depth, to determine bulk density (Bd) by the method of known volume and soil moisture $(\mathrm{Sm})$ through gravimetric analysis. The determination of the soil texture was carried out using the Bouyoucos method. Infiltration tests were carried out for a period of $180 \mathrm{~min}$ and continuously for each point, with standard double ring infiltrometers of 0.2 and $0.4 \mathrm{~m}$ internal and external diameter, respectively, and height of $0.4 \mathrm{~m}$, with which equipment a constant level of water was maintained over the soil surface and the cumulative infiltration $(\mathrm{Ci})$ was determined. With the data obtained, fits were made using the model that shows the cumulative infiltration in an elapsed time in a vertical flow (Philip model), on the basis of which the basic infiltration (Bi), the sorptivity $\left(S_{l}\right)$, and the saturated hydraulic conductivity $(K s)$ were defined. This model takes the form of Equation [1] (Gil, 2002):

$$
I(t)=S_{1} t^{12}+S_{2} t+S_{3} t^{32}+\cdots+S_{n} t^{n 2}+K s t
$$

Philip (1957) elaborated a summary form of Equation [1] with two fitting parameters, sufficient to describe the behavior of the infiltration in relation to time (Equation [2]):

$$
I(t)=S_{1} t^{12}+K s t
$$

where $S_{l}$ is the sorptivity $\left(\mathrm{cm} \mathrm{h}^{-0,5}\right)$ and describes the water absorption by the soil as a result of the gradient of the matrix potential and $K s$ is the saturated hydraulic conductivity $\left(\mathrm{cm} \mathrm{h}^{-1}\right)$. Some authors define the constant $K s$ as an adjustment parameter (Lima and Silans, 1999) or a factor (Machiwal et al., 2006), specifying it as a transitive constant that depends on the initial water content and the soil conditions.

Through Equations [1] and [2] it is shown that when soil moisture is low, the initial rate of infiltration is high, due to the sorptivity, but with time the infiltration rate reaches a constant value, which is defined as the $\mathrm{Bi}$ and is similar to the saturated hydraulic conductivity (Gil, 2002). The fit of Equation [2] was carried out by means of simple linear regression, with the program Curve Expert 
v.1.3 (Daniel Hyams, Hixson, Tennessee, USA).

An analysis was performed through descriptive statistics taking into consideration all the attributes under study, in order to determine behavior, dispersion, and data distribution tendency, by means of the calculation of mean, median, maximum, minimum, skewness, kurtosis, and coefficient of variation (CV), including the KolmogorovSmirnov test. For the analysis of $\mathrm{CV}$, the classification of Warrick and Nielsen (1980) was used, which defines as low variability a $\mathrm{CV}<12 \%$, medium variability for $\mathrm{CV}$ between 12 and $60 \%$, and high variability for values > $60 \%$.

Later analysis of Pearson linear correlation was performed, together with the cluster analysis (CA), with the aim of estimating the correlation that exists between the soil attributes. The results of the CA are represented in graphic form (dendrogram), in order to facilitate the identification of the groups formed by the attributes, together with the representation of the variation of the Euclidean distance between the attributes in order to define the point at which a dependency among the parameters exists. The analysis of the descriptive and multivariate statistics was performed with the program SPSS v. 17 (SPSS Inc., Chicago, Illinois, USA).

To determine the spatial dependency of the attributes, the theory of regionalized variables was used, in which data were fit to theoretical models, called semivariograms $\gamma(\mathrm{h})$. The experimental semivariogram is defined by:

$$
\gamma(h)=\frac{1}{2 N(h)} \sum_{i=1}^{n(h)}\left[z\left(x_{i}\right)-z\left(x_{i}+h\right)\right]^{2}
$$

where $z(x)$ is the value of the variable at site $x, z\left(x_{i}+h\right)$ is another sample value separated by a distance $h$ and $\mathrm{N}$ is the number of pairs separated by a distance $\mathrm{h}$. The semivariogram is defined as the arithmetic mean of all the squares of the differences between pairs of experimental values separated by a distance $h$, or increments variance of the regionalized variable in localizations separated a distance h (Sepaskhah et al., 2005).

There are diverse theoretical models that can be fit to the experimental semivariogram. In Webster and Oliver (2007) a discussion with respect to the characteristics and conditions that these should meet is presented. In general, such models can be divided into non unbounded (linear, logarithmic, potential) and bounden (spherical, exponential, Gaussian). The bounded models are those of greater application in the spatial variability study of the soil attributes. These models have three common parameters, which are the nugget $\left(\mathrm{C}_{0}\right)$, the sill $\left(\mathrm{C}_{0}+\mathrm{C}\right)$, and the range (a). The nugget indicates the discontinuity among samples, which is to say the spatial variability not detected during the sampling process. The sill is the value of the semivariance where the model is stabilized and shows a constant value. The range represents the distance where this constant correlation is reached; indicating that on the basis of this distance there is no correlation among samples. Equations [4], [5], and [6] show the expressions that define the spherical, exponential and Gaussian semivariograms, respectively.

$$
\begin{gathered}
\gamma(h)=\left\{\begin{array}{l}
C_{0}+C\left(\frac{3}{2}\left(\frac{h}{a}\right)-\frac{1}{2}\left(\frac{h}{a}\right)^{3}\right) \\
C_{0}+C
\end{array} \quad h>a\right. \\
\gamma(h)=C_{0}+C\left(1-\exp \left(\frac{-3 h}{a}\right)\right) \\
\gamma(h)=C_{0}+C\left(1-\exp \left(\frac{-3 h^{2}}{a^{2}}\right)\right)
\end{gathered}
$$

The spherical model has a high growth rate, although for large distances the marginal increments diminish until they become null. The exponential and Gaussian models are applied when the spatial dependence shows a continuous growth in proportion to the distance between the observations, where the spatial dependence vanishes at a distance that tends toward the infinite.

The models were calculated with the program GS+ (Gamma Design Software, LLC, Plainwell, Michigan, USA), which for the selection of the model takes into consideration the greatest coefficient of determination $\left(\mathrm{R}^{2}\right)$, the least sum of squared residuals (SSR), and the value closest to 1 of the coefficient of correlation obtained by the cross validation consistency (CVC) method. Once the model was defined, for each attribute, the degree of spatial dependence (DSD) was verified, on the basis of the relationship between the nugget and the sill $\left(\mathrm{C} / \mathrm{C}_{0}+\mathrm{C}\right)$. The DSD is classified as strong if it is $>0.75$, moderate with values between 0.25 and 0.75 , and weak when it is < 0.25 (Cambardella et al., 1994). When the DSD is close to zero, the model fit to the experimental semivariogram is called the nugget effect (Goovaerts, 1999), and is defined by $\gamma(\mathrm{h})=\mathrm{C}_{0}$, for $\mathrm{h}>0$, denoting a random spatial distribution of the variable.

After evaluating the spatial dependence by attribute, the ordinary kriging technique was implemented (Sepaskhah et al., 2005) to carry out spatial prediction at sites not sampled and finally build contour maps by attribute, using the program Surfer v.9 (Golden Software, Golden, Colorado, USA).

\section{RESULTS AND DISCUSSION}

Most attributes evaluated showed a symmetric distribution, observed in the similar values of mean and median and verified by the skewness and kurtosis coefficients close to zero, showing a behavior that approaches to normal distribution (Grego and Vieira, 2005), as is confirmed by the Kolmogorov-Smirnov test (Table 1). The basic infiltration $(\mathrm{Bi})$ and clay content differ from this behavior. More importantly than normality, one should verify that the normal distribution does not show any elongated tails, since they can compromise the results that are obtained on the basis of the observed data (Cressie, 1993), especially when interpolation with kriging is carried out, a method 
Table 1. Descriptive statistics of soil physical attributes.

\begin{tabular}{|c|c|c|c|c|c|c|c|c|}
\hline Attribute & Mean & Median & $\mathrm{CV}(\%)$ & Minimum & Maximum & Skewness & Kurtosis & $\mathrm{K}-\mathrm{S}$ \\
\hline $\mathrm{Ci}, \mathrm{cm}$ & 10.11 & 9.75 & 65.71 & 4.40 & 19.80 & 0.65 & 0.08 & \\
\hline $\mathrm{Bi}, \mathrm{cm} \mathrm{h}^{-1}$ & 1.46 & 1.28 & 57.00 & 0.26 & 3.86 & 0.75 & 0.01 & * \\
\hline $\mathrm{S}_{1}, \mathrm{~cm} \mathrm{~h}^{-0.5}$ & 4.77 & 4.79 & 49.13 & 0.54 & 10.70 & 0.5 & -0.05 & \\
\hline $\mathrm{Ks}, \mathrm{cm} \mathrm{h}^{-1}$ & 0.80 & 0.72 & 57.79 & 0.01 & 1.94 & 0.54 & -0.16 & \\
\hline $\mathrm{Bd}, \mathrm{g} \mathrm{cm}^{-3}$ & 1.87 & 1.90 & 5.83 & 1.56 & 2.07 & -0.62 & 0.08 & \\
\hline $\mathrm{Sm}, \%$ & 4.47 & 4.29 & 35.28 & 2.14 & 8.53 & 0.79 & 0.22 & \\
\hline Sand, $\%$ & 40.34 & 40.34 & 5.96 & 34.70 & 45.95 & -0.03 & -0.55 & \\
\hline Silt, \% & 36.60 & 36.83 & 5.62 & 32.21 & 40.96 & 0.05 & -0.65 & \\
\hline Clay, \% & 22.84 & 22.75 & 9.01 & 18.73 & 29.89 & 1.07 & 2.55 & * \\
\hline
\end{tabular}

CV: coefficient of variation; K-S: Kolmogorov-Smirnov test ( $\mathrm{p} \leq 0.05)$; Ci: cumulative infiltration; Bi: basic infiltration; $\mathrm{S}_{1}$ : sorptivity; Ks: saturated hydraulic conductivity; Bd: bulk density; Sm: soil moisture.

"Significant.

that bases estimations on mean values (Warrick and Nielsen, 1980). Another important element to verify is the occurrence of the proportional effect between mean and variance of samples in space, since this effect allows estimating sills defined in semivariogram models.

The sand, silt and clay contents present the ranges reported by Ramírez-López et al. (2008) in the same region and soil class, whose soil texture varies between loam and clay loam. These authors affirm that this soil shows natural compaction processes of the soil aggregates, which justifies the high values found for the bulk density $(\mathrm{Bd})$, whose reported values are less in a study carried out in the rainy season of the same region (Jaimes et al., 2003). The Ks showed values less than that of loamy soils, according to Clapp and Homberger (1978). These values of $K s$ indicate that the water flow is slow and there are some places with moderate $K s$, but with water flow restrictions.

According to Warrick and Nielsen (1980), the variables sand, silt, clay, and $\mathrm{Bd}$ showed low variability, $\mathrm{Bi}, S_{l}, K s$, and $\mathrm{Sm}$ showed medium variability, while the cumulative infiltration $(\mathrm{Ci})$ showed high variability. These results are similar to those reported by Ramírez-López et al. (2008) in the same area of study and for the same Oxisol, a region that has high temperatures and rainfall above $2000 \mathrm{~mm}$ $\mathrm{yr}^{-1}$. In general, these attributes show high variability (Rodríguez-Vásquez et al., 2008; Cucunubá-Melo et al., 2011) especially at the soil surface or in highly intervened (Zimmermann and Elsenbeer, 2008).

The Pearson test showed direct and significant correlations between $\mathrm{Ci}, \mathrm{Bi}, S_{I}$ and $K s$, attributes that correspond to water infiltration process (Table 2). Usually $K s$ and $S_{l}$ exhibit similar tendency (Abrisqueta et al., 2006). In turn, these attributes showed an inverse

Table 2. Pearson correlation of soil attributes.

\begin{tabular}{lrrlllllll}
\hline & $\mathrm{Ci}$ & $\mathrm{Bi}$ & $\mathrm{S}_{1}$ & $\mathrm{Ks}$ & $\mathrm{Bd}$ & $\mathrm{Sm}$ & Sand & Silt & Clay \\
\hline $\mathrm{Ci}$ & 1 & $* *$ & $* *$ & $* *$ & $*$ & $\mathrm{~ns}$ & $\mathrm{~ns}$ & $\mathrm{~ns}$ & $\mathrm{~ns}$ \\
$\mathrm{Bi}$ & 0.841 & 1 & $* *$ & $* *$ & $* *$ & $\mathrm{~ns}$ & $\mathrm{~ns}$ & $\mathrm{~ns}$ & $\mathrm{~ns}$ \\
$\mathrm{~S}$ & 0.928 & 0.643 & 1 & $* *$ & $*$ & $*$ & $\mathrm{~ns}$ & $\mathrm{~ns}$ & $\mathrm{~ns}$ \\
$\mathrm{Ks}$ & 0.706 & 0.745 & 0.453 & 1 & $\mathrm{~ns}$ & $\mathrm{~ns}$ & $\mathrm{~ns}$ & $\mathrm{~ns}$ & $\mathrm{~ns}$ \\
$\mathrm{Bd}$ & -0.303 & -0.379 & -0.266 & -0.19 & 1 & $\mathrm{~ns}$ & $* *$ & $\mathrm{~ns}$ & $* *$ \\
$\mathrm{Sm}$ & 0.170 & 0.025 & 0.261 & -0.087 & -0.047 & 1 & $* *$ & $\mathrm{~ns}$ & $* *$ \\
Sand & -0.094 & -0.143 & -0.126 & -0.019 & 0.365 & -0.368 & 1 & $* *$ & $* *$ \\
Silt & $\mathbf{- 0 . 0 0 5}$ & $\mathbf{0 . 0 5 5}$ & $\mathbf{- 0 . 1 1 0}$ & $\mathbf{0 . 1 9 3}$ & $\mathbf{- 0 . 0 8 8}$ & $\mathbf{- 0 . 1 4 0}$ & $\mathbf{- 0 . 4 3 5}$ & 1 & $* *$ \\
Clay & 0.106 & 0.123 & 0.209 & -0.102 & -0.344 & 0.492 & -0.821 & -0.821 & 1 \\
\hline
\end{tabular}

"p $\leq 0.05 ;{ }^{* 2} \mathrm{p} \leq 0.01$; ns: non significant; $\mathrm{Ci}$ : cumulative infiltration; Bi: basic infiltration; $\mathrm{S}_{1}$ : sorptivity; Ks: saturated hydraulic conductivity; Bd: bulk density; Sm: soil moisture. correlation with $\mathrm{Bd}$, which indicates that the water flow in the soil is restricted by the high values of $\mathrm{Bd}$. It can be observed that the process of infiltration is weakly influenced by the sand and clay contents (Haghighi et al., 2010), as is confirmed by the low values of coefficients of correlation between those attributes with respect to $\mathrm{Ci}$, $\mathrm{Bi}, S_{l}$, and $K s$, possibly explained by the native savannah condition of the soil and the lower variability that sand and clay content. In the same way, a direct relationship between clay and Sm can be observed, and an inverse one between sand and $\mathrm{Sm}$, which indicates that a high clay content, greater soil moisture, and thus the greater capacity for water storage.

The low correlation shown by $\mathrm{Sm}$ in the attribute of infiltration studied is noteworthy, in that $S_{1}$ was the only attribute that showed a significant correlation with $\mathrm{Sm}$. This situation is expressed by the low soil water content (lower than the wilting point, according to data reported by Jaimes et al., 2003), and given that the study was carried out at the end of the dry season, presumably soil water content in subsurface horizons was equally low at the time of the study, a situation that creates resistance to water flow (Jaramillo y Vanegas, 2007).

The dendrogram (Figure 1A) shows clusters where groups that describe the relationship between attributes and that correspond to results obtained for Pearson correlation are observed (Table 2). Each time a marked variation in the values of the Euclidean distance is shown, it is possible to identify the groups. For the present study, this greater variation can be observed in step 7 (Figure 1B), where the Euclidean distance goes from a value of 10.5 to 18.1 , resulting in three groups.

Group I is made up of Sm, sand and silt content, a situation that confirms that soil water content is directly related to clay and sand content. Group II is made by $\mathrm{Bd}$ and sand, a relationship that was significant in the Pearson correlation, showing that sand content influences $\mathrm{Bd}$. Group III is composed of $K s, I b, S_{l}$, and $\mathrm{Ci}$, attributes that allow describing water movement in the soil and that show the greatest correlations, since they were determined on the basis of the experimental infiltration curve, with the exception of $\mathrm{Ci}$, which was obtained by node upon finishing the infiltration test. The smallest Euclidean distances reported for this group show the 

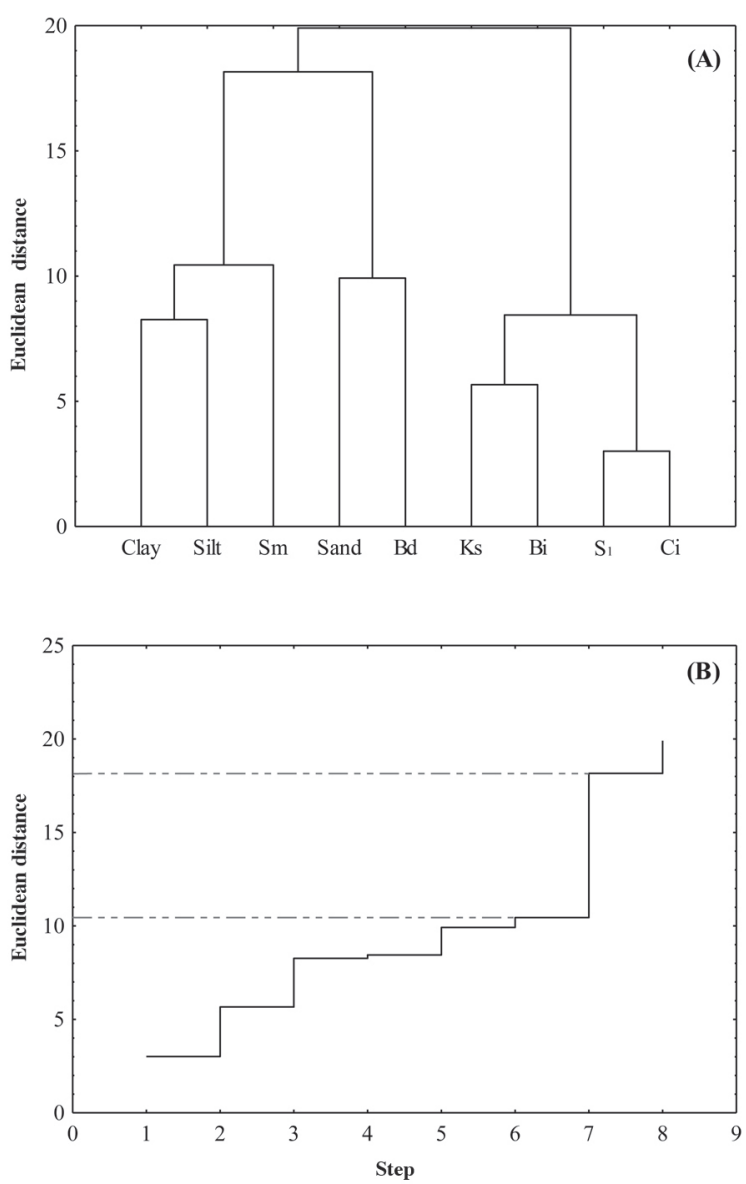

Sm: soil moisture; Bd: bulk density; Ks: saturated hydraulic conductivity; Bi: basic infiltration; $\mathrm{S}_{1}$ : sorptivity; Ci: cumulative infiltration.

Figure 1. Dendrogram of cluster analysis of soil attributes (A) and representation of the Euclidean distance variation between attributes (B).

strong correlation between these attributes, as observed in the correlation of Pearson.

The predominant semivariogram model was exponential, followed by gaussian and spherical models, for those attributes that showed a fit (Table 3). The $\mathrm{Ci}$ and Ks showed a nugget effect (NE); that is, they did not show defined spatial dependence. As was suggested by Bagarello and Sgroi (2007), random behavior of these attributes can be attributed to the variability found, which was high and medium, respectively $(\mathrm{CV}=65.71 \%$ and $\mathrm{CV}=57.79 \%$ ), in spite of the fact that initially the statistical analysis shows a behavior close to the normal for these attributes. Moreover, under conditions of soil moisture content at the time of testing infiltration as well as by natural compaction processes, allow to verify the presence of macropores is low and the incidence of repellency affected the lack spatial dependence of these attributes (Sepaskhah et al., 2005; Moody et al., 2009).

The attribute that showed the least coefficient of determination $\left(\mathrm{R}^{2}\right)$ was silt, with a value of 0.66 . The rest of attributes showed a range of $\mathrm{R}^{2}$ between 0.80 and 0.97 , values that show a reliable fit with the data of semivariograms, which is confirmed by the proximity to 1 of CVC. Similar results for spatial dependence have been found by other authors (Rodríguez-Vásquez et al., 2008; Martins et al., 2010).

The smallest ranges were shown for $\mathrm{Bi}$ and silt, with $174 \mathrm{~m}$ and $186 \mathrm{~m}$, respectively, where $\mathrm{Bd}$ was the attribute that showed the greatest range $(648 \mathrm{~m})$. The maximum distance of the sampling considered for the analysis of the semivariograms was $791.60 \mathrm{~m}$, and for the construction of the theoretical semivariograms $650 \mathrm{~m}$ was used, which equals at least $90 \%$ of the maximum distance of the sampling, a parameter that fits the theory of regionalized variables (Penížek and Borůvka, 2004).

The attributes that defined the soil water movement showed a moderate DSD, Bd constituting the attribute with least DSD (0.53) and clay that which showed the greatest DSD (0.96). The DSD close to one showed the reliability of the fit of data to theoretical semivariograms, a necessary condition for the interpolation of variables in the elaboration of contour maps.

Contour maps confirm the existence of spatial variability of evaluated attributes (Figure 2), defined by heterogeneity and complexity that link hydrophysical attributes, among which size, form, and continuity of pores and of soil aggregates, which in turn determine the size and roots development (Imhoff et al., 2010). In sequence, contour maps offer the possibility of identifying soil sectors where greater or lesser water deficit exists, as a function of the hydrodynamic parameters $\mathrm{Bi}$ and $S_{l}$, with which the conditions of management of the time and water layers application can be optimized, as well as the frequency of irrigation, which can diminish production costs, at the same time as the presence of degrading processes would be diminished, especially the formation of surface run-off, when one decides to supply a uniform irrigation layer.

These graphic representations revalidate the relationships found by Pearson correlation and hierarchical analysis. Existing correlations among attributes of sand and clay are confirmed, demonstrating that zones of high sand content correspond to zones with a low amount of clay. The influence of sand content on

Table 3. Parameters of the semivariogram models obtained for soil attributes.

\begin{tabular}{llrrrrrr}
\hline Attribute & \multicolumn{1}{c}{ Model } & Co & Co $+\mathrm{C}$ & $\begin{array}{c}\text { Range } \\
\mathrm{m}\end{array}$ & $\mathrm{C} / \mathrm{C}+\mathrm{C}_{0}$ & $\mathrm{R}^{2}$ & $\mathrm{CVC}$ \\
\hline $\mathrm{Ci}$ & NE & 26.600 & 26.600 & & & & \\
$\mathrm{Bi}$ & Exponential & 0.405 & 2.774 & 186 & 0.85 & 0.80 & 0.93 \\
$\mathrm{~S}_{1}$ & Exponential & 2.565 & 5.131 & 429 & 0.50 & 0.89 & 0.92 \\
$\mathrm{Ks}$ & NE & 0.381 & 0.381 & & & & \\
$\mathrm{Bd}$ & Gaussian & 0.006 & 0.014 & 648 & 0.53 & 0.92 & 0.87 \\
$\mathrm{Sm}$ & Gaussian & 1.309 & 3.005 & 598 & 0.56 & 0.86 & 0.91 \\
Sand & Spherical & 0.910 & 10.690 & 279 & 0.92 & 0.93 & 1.05 \\
Silt & Exponential & 0.570 & 3.831 & 174 & 0.85 & 0.66 & 0.88 \\
Clay & Spherical & 0.610 & 15.480 & 426 & 0.96 & 0.97 & 0.98
\end{tabular}

$\mathrm{C}_{0}$ : nugget; $\mathrm{C}_{0}+\mathrm{C}$ : sill; $\mathrm{C} / \mathrm{C}+\mathrm{C}_{0}$ : degree of spatial dependence; $\mathrm{R}^{2}$ : coefficient of determination; $\mathrm{CVC}$ : cross validation coefficient; $\mathrm{NE}$ : nugget effect; $\mathrm{Ci}$ : cumulative infiltration; Bi: basic infiltration; $\mathrm{S}_{1}$ : sorptivity; Ks: saturated hydraulic conductivity; Bd: bulk density; Sm: soil moisture. 

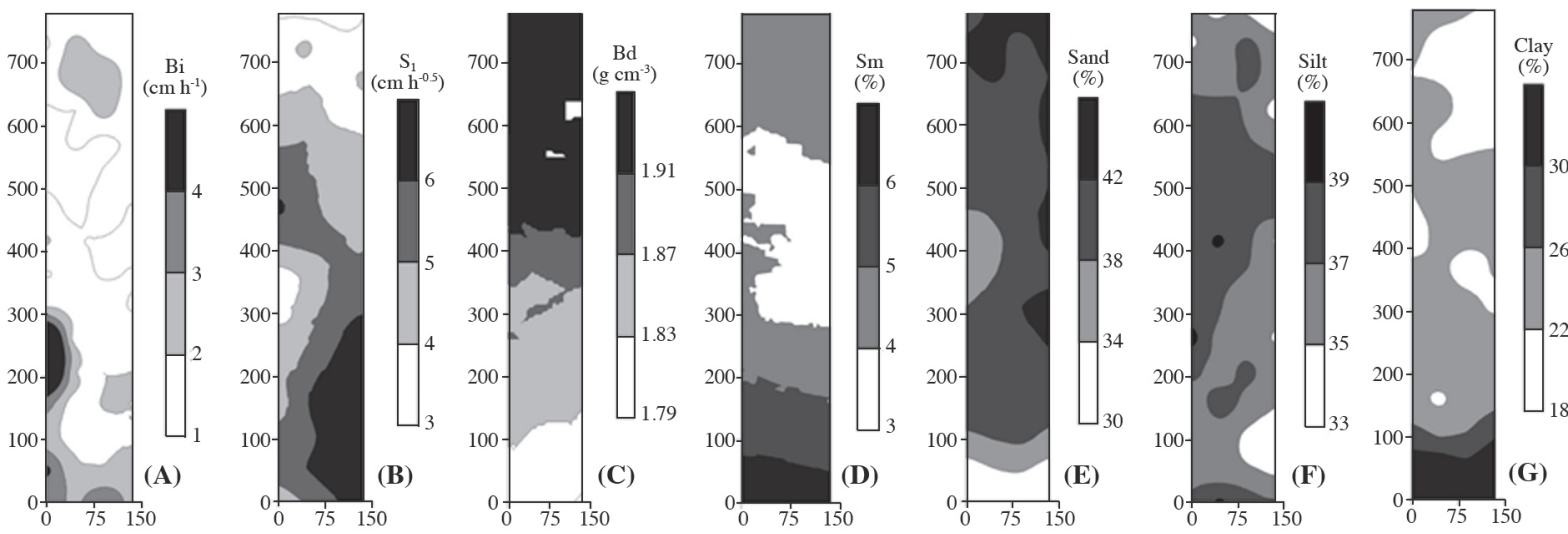

Bi: Basic infiltration; $\mathrm{S}_{1}$ : sorptivity; Bd: bulk density; Sm: soil moisture.

Figure 2. Contour maps obtained by kriging of basic infiltration (A), sorptivity (B), bulk density (C), soil moisture (D), and sand (E), silt (F), and clay $(\mathbf{G})$ contents.

Bd can also be observed, where those zones that showed high sand content showed greater values of $\mathrm{Bd}$. The direct relationship found between $\mathrm{Bi}$ and $\mathrm{S}_{1}$ can equally be observed in maps obtained for these attributes.

\section{CONCLUSIONS}

Savanna soils of Eastern Plains (Llanos Orientales) show physical limitations by natural processes of compaction, as observed by high bulk density values, which restricts water and air movement, which in turn affects plant development. These physical limitations vary in space and can be identified through different hydrophysical attributes generally correlated with each other and follow a spatial distribution.

The main number of attributes that showed significant correlations were also the highest expression in the cluster analysis and in turn, which showed better similarity in their spatial variability, as observed between maps obtained by kriging for attributes that were fitted to theoretical models of semivariograms.

The use of descriptive statistics allowed identifying the existence of variability of soil physical attributes, as well as parameters of water infiltration, which in the majority fit distribution patterns that were modeled using geostatistical techniques, which allowed attributes prediction in non-sampled zones, through interpolation algorithms such as kriging. In the same way, different relationships between soil attributes can be established, where simple techniques like Pearson correlation or cluster analysis allow visualizing the linear correlation between pairs of attributes, relationships that also can be seen especially using geostatistical techniques, which let obtaining detailed and practical information, in order to facilitate the management of fundamental resources in agricultural production, such as soil and principally water, in order to establish zones of management of the design, adjustment and operation of irrigation systems.

\section{ACKNOWLEDGEMENTS}

To the Research Division (DIB) of the National University of Colombia at Bogotá, for its economic support for the development of the present study. To the Colombian Corporation for Agricultural Research (CORPOICA) for authorizing the development of the present study at the Taluma Experimental Station and for its field support.

Análisis espacial de la infiltración en un Oxisol de los llanos orientales de Colombia. Estudios que involucran la variabilidad de los atributos del suelo, ayudan al análisis del comportamiento de las variables hidrofísicas en el espacio, para apoyar la toma de decisiones bajo la concepción de agricultura de precisión. El objetivo del presente trabajo fue caracterizar la variabilidad espacial de la infiltración superficial y su relación con algunos atributos físicos del suelo. El muestreo se realizó en una malla rectangular de 64 puntos, con distancias perpendiculares de $52 \mathrm{~m} \times 45 \mathrm{~m}$ entre puntos de muestreo. Los atributos estudiados fueron densidad aparente, contenidos de arena, limo y arcilla, humedad del suelo, infiltración acumulada, infiltración básica, sortividad y conductividad hidráulica saturada (Ks). Los datos se analizaron mediante estadística descriptiva y geoestadística, identificando la relación entre los atributos, mediante la correlación de Pearson y agrupamiento jerárquico. Los resultados sugieren un comportamiento de los parámetros cercano a la normalidad, donde los atributos relacionados con el movimiento del agua en el suelo presentaron mayor variabilidad, con valores bajos de infiltración básica $\left(1,46 \mathrm{~cm} \mathrm{~h}^{-1}\right)$ y Ks $\left(0,80 \mathrm{~cm} \mathrm{~h}^{-1}\right)$, que junto con los altos valores de densidad aparente $(1,87$ $\left.\mathrm{g} \mathrm{cm}^{-3}\right)$, muestran limitaciones por compactación. La infiltración acumulada y Ks fueron los únicos atributos que no se ajustaron a modelos de distribución espacial, encontrándose alcances superiores de $150 \mathrm{~m}$ para los otros atributos, distancia que permite optimizar muestreos futuros para el estudio de la variabilidad espacial. La 
correlación de Pearson y el análisis clúster permitieron establecer las relaciones entre los atributos del suelo, relaciones que fueron corroboradas espacialmente en los mapas de contorno, donde se observó la influencia de los contenidos de arcilla y arena en el comportamiento de la densidad aparente, y de estos atributos en los procesos de infiltración de agua en el suelo.

Palabras clave: geoestadística, conductividad hidráulica, infiltración, sortividad.

\section{LITERATURE CITED}

Abrisqueta, J.M., V. Plana, J.A. Franco, and M.C. Ruiz-Sánchez. 2006. Effect of tillage and water pressure head on the hydraulic properties of a loamy soil surface. Spanish Journal of Agricultural Research 4:180-186.

Bagarello, V., C. Di Stefano, V. Ferro, M. Iovino, and A. Sgroi. 2010. Physical and hydraulic characterization of a clay soil at the plot scale. Journal of Hydrology 387:54-64.

Bagarello, V., and A. Sgroi. 2007. Using the simplified falling head technique to detect temporal changes in field-saturated hydraulic conductivity at the surface of a sandy loam soil. Soil and Tillage Research 94:283-294.

Borůvka, L., H. Donátová, and K. Němeček. 2002. Spatial distribution and correlation of soil properties in a field: a case study. Rostlinná Výroba 48:425-432.

Cambardella, C.A., T.B. Moorman, J.M. Novak, T.B. Parkin, D.L. Karlen, R.F. Turco, and A.E. Konopka. 1994. Field-scale variability of soil properties in Central Iowa Soils. Soil Science Society of America Journal 58:1501-1511.

Clapp, R.B., and G.M. Homberger. 1978. Empirical equations for some soil hydraulic properties. Water Resources Research 14:601604.

Cressie, N. 1993. Statistics for spatial data. Revised Edition. 928 p. John Wiley \& Sons, New York, USA.

Cucunubá-Melo, J.L., J.G. Álvarez-Herrera, and J.H. CamachoTamayo. 2011. Identification of agronomic management units based on physical attributes of soil. Journal of Soil Science and Plant Nutrition 11:87-99.

Dong-Sheng, Y., Z. Zhong-Qi, Y. Hao, S. Xue-Zheng, T. Man-Zhi, and W. Wei-Xia. 2011. Effect of soil sampling density on detected spatial variability of soil organic carbon in a red soil region of China. Pedosphere 21:207-213.

Garten Jr., C.T., S. Kang, D.J. Brice, C.W. Schadt, and J. Zhou. 2007. Variability in soil properties at different spatial scales $(1 \mathrm{~m}-1 \mathrm{~km})$ in a deciduous forest ecosystem. Soil Biology and Biochemistry 39:2621-2627.

Gil, R.C. 2002. El comportamiento físico-funcional de los suelos. 19 p. Instituto Nacional de Tecnología Agropecuaria (INTA), Instituto de Suelos, INTA Castelar, Buenos Aires, Argentina.

Goovaerts, P. 1999. Geostatistics in soil science: State-of-the-art and perspectives. Geoderma 89:1-45.

Grego, C.R., and S.R. Vieira. 2005. Variabilidade espacial de propriedades físicas do solo em uma parcela experimental. Revista Brasileira de Ciência Do Solo 29:169-177.

Haghighi, F., M. Gorji, M. Shorafa, F. Sarmadian, and M.H. Mohammadi. 2010. Evaluation of some infiltration models and hydraulic parameters. Spanish Journal of Agricultural Research 8:210-217

Imhoff, S., P.J. Ghiberto, A. Grioni, and J.P. Gay. 2010. Porosity characterization of Argiudolls under different management systems in the Argentine Flat Pampa. Geoderma 158:268-274.
Jaimes, W., G. Navas, C. Salamanca, y A. Conde. 2003. Estudio detallado de suelos de la Estación Experimental de CORPOICA "Sabanas" en la Altillanura Colombiana. 62 p. CORPOICA, C.I. La Libertad, Villavicencio, Colombia.

Jaramillo, D.F., and H.A. Vanegas. 2007. Efecto de la temperatura de secado sobre el grado y la variabilidad espacial de la repelencia al agua en Andisoles de Antioquia, Colombia. Revista Facultad Nacional de Agronomía 60:4025-4035.

Lima, C.A.G., and A.P. Silans. 1999. Variabilidade espacial da infiltração de água no solo. Pesquisa Agropecuaria Brasileira 34:2311-2320.

Machiwal, D., M. Jha, and B.C. Mal. 2006. Modelling infiltration and quantifying spatial soil variability in a Wasteland of Kharagpur, India. Biosystems Engineering 95:569-582.

Mallants, D., B.P. Mohanty, D. Jacques, and J. Feyen. 1996. Spatial variability of hydraulic properties in a multi-layered soil profile. Soil Science 161:167-181

Martins, A.L.S., E.G. Moura, and J.H. Camacho-Tamayo. 2010 Spatial variability of infiltration and its relationship to some physical properties. Ingeniería e Investigación 30:116-123.

Moody, J.A., D.A. Kinner, and X. Úbeda. 2009. Linking hydraulic properties of fire-affected soils to infiltration and water repellency. Journal of Hydrology 379:291-303.

Penížek, V., and L. Borůvka. 2004. Processing of conventional soil survey data using geostatistical methods. Plant Soil and Environment 50:352-357.

Philip, J.R. 1957. The theory of infiltration: 4. Sorptivity and algebraic infiltration equations. Soil Science 84:257-265.

Plant, R.E. 2001. Site-specific management: the application of information technology to crop production. Computers and Electronics in Agriculture 30:9-29.

Ramírez-López, L., A. Reina-Sánchez, and J.H. Camacho-Tamayo. 2008. Variabilidad espacial de atributos físicos de un Typic Haplustox de los Llanos Orientales de Colombia. Engenharia Agrícola 28:55-63.

Reynolds, W.D., and D.E. Elrick. 1990. Ponded infiltration from a single ring: I. Analysis of steady flow. Soil Science Society of America Journal 54:1233-1241.

Reynolds, W.D., D.E. Elrick, and E.G. Youngs. 2002. A single-ring and double- or concentric-ring infiltrometers. p. 821-826. In: Dane, J.H., and G.C. Topp (eds.) Methods of soil analysis. Part 4. Physical methods. Number 5 in the Soil Science Society of America Book Series, Soil Science Society of America, Madison, Wisconsin, USA.

Rodríguez-Vásquez, A.F., A.M. Aristizábal-Castillo, and J.H Camacho-Tamayo. 2008. Variabilidad espacial de los modelos de infiltración de Philip y Kostiakov en un suelo Ándico. Engenharia Agrícola 28:64-75

Sepaskhah, A.R., S.H. Ahmadi, and A.R. Nikbakht Shahbazi. 2005 Geostatistical analysis of sorptivity for a soil under tilled and notilled conditions. Soil and Tillage Research 83:237-245.

Tricker, A.S. 1978. The infiltration cylinder: Some comments on its use. Journal of Hydrology 36:383-391.

Warrick, A., and D. Nielsen. 1980. Spatial variability of soil physical properties in the field. p. 319-344. In Hillel, D. (ed.) Applications of soil physics. Academic Press, New York, USA

Webster, R., and M.A. Oliver. 2007. Geostatistics for environmental scientists. John Wiley \& Sons, Hoboken, New Jersey, USA.

Wu, L., L. Pan, M.J. Roberson, and P.J. Shouse. 1997. Numerical evaluation of ring-infiltrometers under various soil conditions. Soil Science 162:771-777.

Youngs, E.G. 1987. Estimating hydraulic conductivity values from ring infiltrometer measurements. Journal of Soil Science 38:623632.

Zimmermann, B., and H. Elsenbeer. 2008. Spatial and temporal variability of soil saturated hydraulic conductivity in gradients of disturbance. Journal of Hydrology 361:78-95. 